\title{
MOOC Design Workshop: Educational Innovation with Empathy and Intent
}

\author{
Yishay Mor ${ }^{1(\bowtie)}$, Steven Warburton ${ }^{2}$, Rikke Toft Nørgård ${ }^{3}$, \\ and Pierre-Antoine Ullmo ${ }^{1}$ \\ 1 PAU Education, Barcelona, Spain \\ \{yishay.mor, pa.ullmo\}@paueducation.com \\ 2 University of Surrey, Guildford, UK \\ steven.warburton@surrey.ac.uk \\ 3 Aarhus University, Aarhus, Denmark \\ rtoft@tdm.au.dk
}

\begin{abstract}
For the last two years we have been running a series of successful MOOC design workshops. These workshops build on previous work in learning design and MOOC design patterns. The aim of these workshops is to aid practitioners in defining and conceptualising educational innovations (predominantly, but not exclusively MOOCs) which are based on an empathic user-centered view of the target learners and teachers. In this paper, we share the main principles, patterns and resources of our workshops and present some initial results for their effectiveness.
\end{abstract}

Keywords: MOOCs $\cdot$ Learning design $\cdot$ Learning experience design • Professional development • User-centered design · Learner-centered design

\section{Introduction}

The MOOC phenomena has opened up the field of online and blended education to institutions and individuals who had never before considered a depart from traditional modes and methods of instruction. Most major universities are either offering MOOCs or in the process of developing MOOCs, while many budget-constrained educational institutions are using MOOCs from high-ranked universities as (open) educational resources, thus developing a new type of hybrid education. We are witnessing institutions and individuals with literally no experience in online teaching (sometimes, with little experience in teaching at all) facing classes of tens of thousands of students, spread across the globe. The challenge that MOOCs present is not just in understanding and addressing the needs of these masses of learners: before that, we need to recognise the needs, desires, and dilemmas of the new breed of online educators, and find effective and principled ways to address them.

Littlejohn and Milligan [9] reviewed the design quality of 76 randomly selected MOOCs. Their results indicate that although most MOOCs are well

(c) The Author(s) 2016

K. Verbert et al. (Eds.): EC-TEL 2016, LNCS 9891, pp. 453-459, 2016.

DOI: $10.1007 / 978-3-319-45153-4 \_42$ 
organised, their instructional design quality is low. Indeed, it seems that most educators that attempt to design and develop a MOOC begin by asking themselves 'what do I need to teach?', or, in other words 'what is the content I need to cover?'. We call this a content-centric approach. The problem with such an approach is that you can produce the most carefully selected content, in the most professionally produced manner, but if learners do not engage with it and make it their own - your efforts will have little lasting effect. In order to provide an effective and meaningful learning experience, we need to focus on the learners - who they are, where are they now (A), and where do we want them to be (B), and how do we guide them in their path from A to B.

\section{Background}

Our work is situated in the Learning Design (LD) tradition. LD is 'the act of devising new practices, plans of activity, resources and tools aimed at achieving particular educational aims in a given situation' [10]. This is a creative process; the designer is bringing new objects into existence. Yet it is also a process of inquiry: the designer needs to understand the situation and establish the efficacy of the objects she creates in bringing about the desired effects. This duality of LD, and the challenges that it poses, has been discussed in depth elsewhere [11].

Engaging educational practitioners in LD has benefits beyond the immediate task [15]. However establishing a design mindset is not trivial [11]. In recent years, there have several attempts to address this issue [2-4,14]. The Learning Design Studio (LDS) draws on these and other frameworks, to offer a process that explicitly interleaves the creative elements of design into a cycle of Design Inquiry of Learning $[12,17]$. In this cycle, participants identify an educational challenge they wish to address, investigate the context of this challenge and the forces that shape it, review relevant theory and practical examples, conceptualise a solution, implement a prototype of that solution, evaluate it and reflect on the process.

The purpose of education, as Dewey eloquently phrased it [5], is to provide learners with the experiences that promote growth. To serve such a cause educational design needs to adopt a clear user-centered position of empathy [1]. This call for empathy is inline with a growing acknowledgement of the role of empathy in design $[6,7,13]$. Postma et al. [13] define empathic design as ' $a$ design research approach that is directed towards building creative understanding of users and their everyday lives for new product development'. They describe creative understanding as a rich combination of cognitive (knowledge) and affective (feeling) perception of the user, which the designer can translate into new products that will meet the user's values, aspirations and constraints. They propose four principles of empathic design: balancing rationality and emotions in building understanding of users' experiences, making empathic inferences about users and their possible futures, involving users as partners, and engaging design team members as multi-disciplinary experts in performing user research. Despite the importance of empathy in education, most LD methodologies do not address the issues of empathy directly. 


\section{The Empathic MOOC Design Workshops}

Following the success of the MOOC design pattern project [16], we turned our attention to the effective support of practitioners wishing to design and produce a new MOOC. Building on the LDS methodology, we designed a workshop format that leads participants through a rapid cycle of design inquiry of learning, with a clear empathic mindset, rooted in a vision of the learners, their values, needs and constraints. This cycle flows through the following phases:

1. Imagine: identify an educational challenge which your MOOC / educational innovation will address.

2. Investigate: Characterise your learners, and describe the transition they will achieve as a result of the educational innovation.

3. Inspire: Review evidence of effective, valuable and meaningful designs, and consider its implications for your educational innovation.

4. Ideate: Use the analysis of effective and valuable designs to conceptualise your educational innovation.

5. Evaluate: Scrutinise your solution to assess its efficacy and value for future learners.

6. Reflect: Take stock of the process you have completed, your achievements and lessons learnt.

These phases are realised through a series of group activities: My Dream MOOC, Personas, Transition Matrix, Force Mapping, Brief, Features and intentions, Educational Instruments, Pattern mapping, Storyboarding, Evaluation rubrics, Presentations, Reflective discussion. Some of these are present in all our workshops, others are selectively used when appropriate. The MOOC design workshops put a strong emphasis on empathy. For this reason, even in a limited time format, we start by considering personas and their expected learning journeys (encoded as a transition matrix). Traditionally, empathic design demands extensive fieldwork [8]. Obviously, this is not possible in a one-off workshop. Instead, we focus on nurturing an empathic mindset. Thus, for example, when participants do not have the capacity to construct persoanas based on observations, we ask them to choose personas from a set we provide. Even in such a seemingly superficial setup, having a persona card before their eyes prompts participants to think, and feel, their design from a learners' perspective.

A detailed description of the activities, with links to supporting resources, is available under a creative commons licence at: https://www.academia.edu/ 26528408/Educational_Innovation_design_kit

\section{Results}

In 2015 and 2016 we ran 8 workshops, 3 of them small, private workshops (up to 10 participants), 5 open workshops at conferences (up to 50 participants). 2 of the private workshops led to successful MOOC/online course projects. One of these was the Amnesty Rights1X course, which had over 30,000 participants. The 
Table 1. Participant feedback from MOOC design workshops $(\mathrm{n}=18)$

\begin{tabular}{l|l|l|l}
\hline Question & Median & Average & SD \\
\hline $\begin{array}{l}\text { I am planning a MOOC, the workshop was valuable for } \\
\text { structuring my thoughts }\end{array}$ & 4 & 3.39 & 1.42 \\
$\begin{array}{l}\text { The workshop raised my awareness to the challenges of } \\
\text { MOOC design }\end{array}$ & 4 & 3.83 & 0.79 \\
\hline $\begin{array}{l}\text { I will use some of the techniques and resources in my } \\
\text { work }\end{array}$ & 4 & 4.11 & 0.9 \\
\hline $\begin{array}{l}\text { I would like to engage my team in a similar, but more } \\
\text { detailed, design process }\end{array}$ & 4 & 3.44 & 1.1 \\
\hline It was fun! & 5 & 4.5 & 0.79 \\
\hline I liked .. Introduction & 4 & 3.67 & 1.19 \\
\hline I liked .. Dream MOOC & 4 & 4 & 0.69 \\
\hline I liked .. Challenge & 4 & 4.25 & 0.62 \\
\hline I liked .. Personas & 5 & 4.39 & 0.78 \\
\hline I liked .. Transition Matrix & 4 & 4.17 & 0.86 \\
\hline I liked .. Feature Cards & 4 & 4.17 & 0.79 \\
\hline I liked .. Design Patterns & 4 & 4.11 & 0.9 \\
\hline I liked .. Storyboarding & 5 & 4.42 & 0.79 \\
\hline I liked .. Evaluate & 4.5 & 3.92 & 1.38 \\
\hline I liked .. Discussion & 4 & 4.17 & 1.04 \\
\hline
\end{tabular}

third private workshop was held quite recently, and we are hoping to see follow-up work. Several additional workshops are scheduled for the spring/summer. Most workshops ran for either half a day or a full day, with exceptional cases being significantly shorter. One workshop was conducted online, all others were face to face. We surveyed the participants at 3 of the open workshops, and collected 18 responses. The median, average and standard deviation of the responses (on a likert scale of 0-5) are shown in Table 1 and Fig. 1.

To the question 'Did you get what you came for?', we received 10 strong positive responses, 3 positive or mildly positive responses, and 2 neutral responses.

Some of the specific comments we received highlighted issues related to empathy: "I especially liked the design patterns and the concept of personas", "(My biggest takeaway is ...) Do take the client and his/her context as the starting point", "(My biggest takeaway is ...) The viewpoint that you start with personas and the transition matrix".

Interestingly, several participants noted: "I think everything that we discussed can be applied to 'normal' online courses, too". 


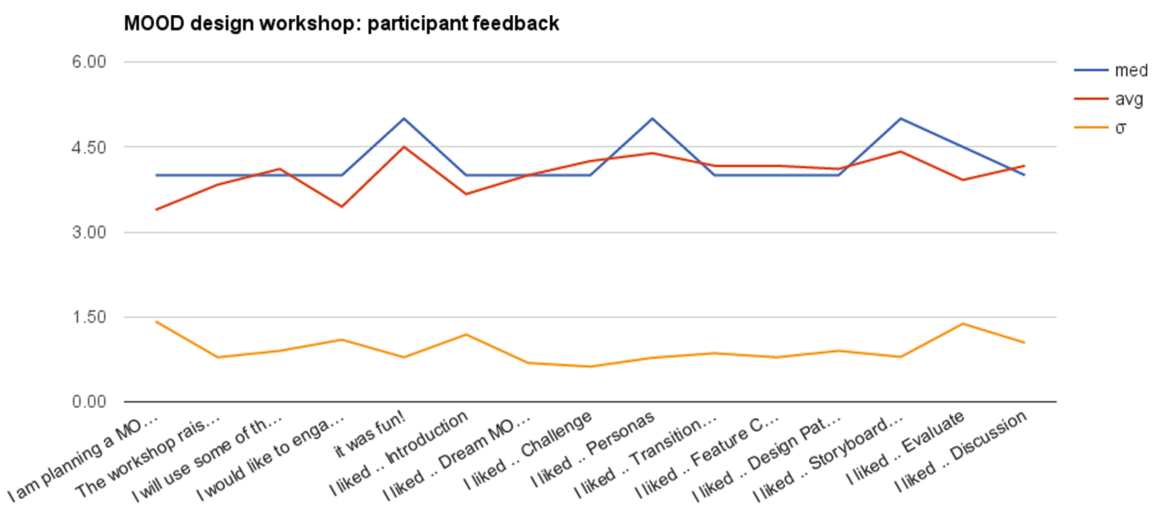

Fig. 1. Participant feedback from MOOC design workshops $(\mathrm{n}=18)$

\section{Conclusions}

The MOOC design workshops are designed to introduce participants to a learnercentered empathic approach to designing MOOCs. This process is rooted in a deep cognitive and emotional understanding of the target learners in the MOOC as holistic learners, their current intentional, physical and social state, the desired effect of the MOOC, and the assets and constraints that shape their zone of possibilities. Analysis of the feedback from the workshops we had surveyed suggests that participants recognise the main messages of the workshop, and acknowledge their value. This analysis is confirmed by the observed outcomes in the MOOCs that have emerged from the workshop and follow-up design consultancy.

The workshops draw on the outputs of the MOOC design patterns project, and are based on the Learning Design Studio framework. They extend this framework by adding a stronger emphasis on empathy, through the use of personas, transition matricis, and force maps.

The workshop design has shown excellent adaptability it is flexible enough to run in as little as 75 min to a whole day. We are planning to expand this to a $M O O C$ design and development sprint where by the prototyping step (mentioned earlier) could be brought into the process over an intensive 3-day session which incorporated digital content developers and media specialists to realise the projects on a designated platform.

The resources we use in our workshops are available under a creative commons licence at: http://moocsandco.com/kit.

Open Access. This chapter is distributed under the terms of the Creative Commons Attribution 4.0 International License (http://creativecommons.org/licenses/by/ $4.0 /$ ), which permits use, duplication, adaptation, distribution and reproduction in any medium or format, as long as you give appropriate credit to the original author(s) and the source, a link is provided to the Creative Commons license and any changes made are indicated. 
The images or other third party material in this chapter are included in the work's Creative Commons license, unless indicated otherwise in the credit line; if such material is not included in the work's Creative Commons license and the respective action is not permitted by statutory regulation, users will need to obtain permission from the license holder to duplicate, adapt or reproduce the material.

\section{References}

1. Aaen, J.H., Nørgård, R.T.: Participatory academic communities: a transdisciplinary perspective on participation in education beyond the institution. Conjunctions. Transdisciplinary J. Cult. Participation 2, 67-98 (2016)

2. Asensio-Péerez, J.I., Dimitriadis, Y., Prieto, L.P., Hernáandez-Leo, D., Mor, Y.: From idea to vle in half a day: metis approach and tools for learning co-design. In: Proceedings of the Second International Conference on Technological Ecosystems for Enhancing Multiculturality, TEEM 2014, pp. 741-745. ACM, New York (2014)

3. Asensio-Prez, J.I., Dimitriadis, Y., Hernndez-Leo, D., Pozzi, F.: Teacher continuous professional development and fulllifecycle learning design: first reflections. In: Garreta-Domingo, M., Sloep, P., Stoyanov, S., Hernndez-Leo, D., Mor, Y. (eds.) Proceedings of the Workshop Design for Learning in Practice, EC-TEL, Toledo, 18 September, 2015

4. Conole, G.: The 7Cs of learning design a new approach to rethinking design practice. In: Proceedings of the 9th International Conference on Networked Learning, pp. 502-509 (2014)

5. Dewey, J.: Experience and Education. Simon and Schuster, New York (1938)

6. Gagnon, C., Ct, V.: Learning from others: a five years experience on teaching empathic design. In: Lim, Y.K., Niedderer, K., Redstrm, J., Stolterman, E., Valtonen, A. (eds.) Proceedings of Design Research Society Biennial International Conference DRS 2014: Designs Big Debates, pp. 16-19. Ume Institute of Design, Ume University, Ume, Sweden, June 2014

7. Köppen, E., Meinel, C.: Empathy via design thinking: creation of sense and knowledge. In: Plattner, H., Meinel, C., Leifer, L. (eds.) Design Thinking Research. Understanding Innovation, pp. 15-28. Springer, Switzerland (2015)

8. Leonard, D., Rayport, J.F.: Spark innovation through empathic design. Harvard Bus. Rev. 75, 102-115 (1997)

9. Littlejohn, A., Milligan, C.: Designing MOOCs for professional learners: tools and patterns to encourage self-regulated learning. e-Learning Papers. 42 (2015)

10. Mor, Y., Craft, B.: Learning design: reflections on a snapshot of the current landscape. Res. Learn. Technol. 20, 85-94 (2012)

11. Mor, Y., Craft, B., Hernndez-Leo, D.: Editorial: the art and science of learning design. Res. Learn. Technol. 21, 1-8 (2013)

12. Mor, Y., Mogilevsky, O.: Learning design studio: educational practice as design inquiry of learning. In: Hernández-Leo, D., Ley, T., Klamma, R., Harrer, A. (eds.) EC-TEL 2013. LNCS, vol. 8095, pp. 233-245. Springer, Heidelberg (2013)

13. Postma, C.E., Zwartkruis-Pelgrim, E., Daemen, E., Du, J.: Challenges of doing emphatic design: experiences from industry. Int. J. Des. 6(1), 59-70 (2012)

14. Salmon, G., Gregory, J., Lokuge Dona, K., Ross, B.: Experiential online development for educators: the example of the carpe diem MOOC. Br. J. Educ. Technol. 46(3), 542-556 (2015) 
15. Voogt, J., Westbroek, H., Handelzalts, A., Walraven, A., McKenney, S., Pieters, J., de Vries, B.: Teacher learning in collaborative curriculum design. Teach. Teach. Educ. 8, 1235-1244 (2011)

16. Warburton, S., Mor, Y.: A set of patterns for the structured design of MOOCs. Open Learn. J. Open Distance e-Learning 30(3), 1-15 (2015)

17. Warburton, S., Mor, Y.: Double loop design: configuring narratives, patterns and scenarios in the design of technology enhanced learning. In: Mor, Y., Maina, M., Craft, B. (eds.) The Art and Science of Learning Design. Sense publishers, Boston (2015) 